\title{
ANALISIS PEMAHAMAN KONSEP KELILING DAN LUAS SEGITIGA PESERTA DIDIK KELAS VIII SMP IT NURUL HUDA KEEROM BERDASARKAN TAKSONOMI BLOOM
}

\author{
Raldi $^{1}$ \\ IAIN Fattahul Muluk Papua, 99351 \\ raldins104@gmail.com \\ Ahmad Arif Rofiki ${ }^{2}$ \\ IAIN Fattahul Muluk Papua, 99351 \\ a.arifrofiki@gmail.com \\ Nining Puji Lestari ${ }^{3}$ \\ IAIN Fattahul Muluk Papua, 99351 \\ lestaning112988@yahoo.com
}

\begin{abstract}
Abstrak
Berdasarkan hasil belajar peserta didik kelas VIII SMP IT Nurul Huda Keerom pada materi segitiga sebagian besar kurang memuaskan. Hal ini membuktikan bahwa pemahaman konsep keliling dan luas segitiga masih rendah dan pemahaman setiap peserta didik berbeda-beda. Penelitian ini bertujuan untuk mengetahui (1) pemahaman konsep keliling dan luas segitiga peserta didik kelas VIII SMP IT Nurul Huda Keerom dan (2) Faktor-faktor yang mempengaruhi pemahaman konsep peserta didik kelas VIII SMP IT Nurul Huda Keerom. Jenis penelitian ini adalah penelitian deskriptif kualitatif. Pendekatan penelitian menggunakan pendekatan pedagogi. Teknik analisis data menggunakan reduksi data, penyajian data, dan penarikan kesimpulan. Penyajian keabsahan datanya yaitu kepercayaan, keteralihan, kebergantungan, dan kepastian. Hasil penelitian menunjukkan bahwa (1) Subjek kemampuan matematika tinggi berada pada tahapan mengaplikasikan, subjek kemampuan matematika sedang berada pada tahapan mengaplikasikan, subjek kemampuan matematika rendah hanya berada pada level tahapan mengingat berdasarkan Taksonomi Bloom. (2) Faktor internal yang mempengaruhi berkemampuan matematika tinggi memiliki kesiapan dalam belajar dan memiliki sedikit minat dalam belajar. Subjek berkemampuan matematika sedang memiliki kesiapan dalam belajar dan memiliki minat untuk belajar. Subjek berkemampuan matematika rendah selalu memiliki kesiapan dalam belajar dan memiliki motivasi dari dalam diri untuk belajar. Sedangkan faktor eksternalnya semua subjek mendapatkan motivasi dari orang tua, guru, dan sekolah.
\end{abstract}

Kata Kunci: Pemahaman Konsep, Taksonomi Bloom dan Faktor Belajar

\section{PENDAHULUAN}

Menurut Ki Hajar Dewantara, pendidikan adalah suatu tuntutan dalam tumbuhnya anakanak. Maksudnya ialah bahwa pendidikan itu menuntun segala kekuatan kodrat yang ada pada diri peserta didik agar sebagai manusia dan anggota masyarakat dapat mencapai keselamatan dan kebahagiaan hidup yang setinggi-tingginya.(Hamid Darmadi, dkk, p.5) Berdasarkan penjelasan Ki Hajar Dewantara tersebut, maka pendidikan penting bagi kehidupan. Melalui pendidikan, manusia dapat hidup dengan pengetahuan atau sumber daya yang tinggi sehingga kehidupan manusia lebih baik dari sebelumnya. 
Matematika merupakan salah satu pendidikan dan pengetahuan dasar yang terpenting baik dalam ilmu sosial maupun dalam bidang ilmu eksak, karena matematika sangat erat hubungannya dengan masalah dalam kehidupan sehari-hari. (Rasid Ode dan Kasriana, 2018) Namun yang terjadi, pada kenyataannya banyak peserta didik yang tidak menyukai matematika dan merasa bosan dalam belajar matematika. Matematika diidentikkan dengan rumus, angka-angka, dan perhitungan. Hal inilah yang kemudian dapat melemahkan semangat belajar peserta didik.

Berdasarkan hasil PISA (Programme for International Student Assessment) tahun 2018, skor Indonesia mengalami penurunan pada kemampuan membaca, matematika, dan sains. Skor Indonesia pada kemampuan matematika yaitu 379 yang sebelumnya 386 pada tahun 2015. Melihat skor tersebut, Indonesia berada pada urutan 71 dari 76 negara. (Feri Yohanes dan Sutriyono, 2018, p.57) Berdasarkan skor dan ranking tersebut, membuktikan bahwa pemahaman konsep matematika di Indonesia masih rendah., sehingga Indonesia perlu mengevaluasi dan membenahi sistem pembelajaran untuk peningkatan pemahaman konsep matematika.

Pembelajaran matematika merupakan suatu keharusan yang diikuti oleh semua peserta didik. Sebagai upaya untuk mengetahui tingkat keberhasilan dan pemahaman konsep peserta didik dalam mencapai tujuan pembelajaran yang diterapkan, maka evaluasi hasil belajar memiliki sasaran tertentu yang terkandung dalam tujuan pembelajaran tersebut. Pengelompokkan tujuan pembelajaran itu harus mengacu kepada tiga jenis domain yang melekat pada diri peserta didik yang disebutkan oleh Benjamin S. Bloom yang dikenal dalam Taksonomi Bloom, yaitu ranah proses berpikir (cognitive domain), ranah nilai atau sikap (affective domain), dan ranah keterampilan (psychomotor domain) (Sugianti Khasanah, 2015, p.64).

Dalam kurikulum 2013, khususnya pada Kompetensi Inti (KI) nomor tiga peserta didik dituntut memiliki kemampuan kognitif sebagai salah satu pembelajaran. Tuntutan kurikulum yang telah dipaparkan sebelumnya, kemampuan kognitif yang harus dikuasai peserta didik sampai pada jenjang menganalisis (C4) ataupun mencipta (C4). Hal tersebut membuat peneliti tertarik melakukan penelitian pada pemahaman konsep peserta didik kelas VIII SMP IT Nurul Huda Keerom untuk melihat sejauh mana SMP IT Nurul Huda Keerom melaksanakan tuntutan dari Kurikulum 2013. Berdasarkan hasil wawancara yang dilakukan peneliti di SMP IT Nurul Huda Keerom, kemampuan matematika peserta didik SMP IT Nurul Huda Keerom berbeda-beda dan memiliki tingkat pemahaman konsep matematika yang berbeda-beda pula. Hal tersebut terjadi di berbagai mata pelajaran bukan hanya di pelajaran matematika. Namun dalam pelajaran matematika, memiliki perbedaan yang signifikan baik kemampuan maupun pemahaman matematika dari peserta didik berkemampuan tinggi dan peserta didik berkemampuan rendah. Terbukti pada hasil belajar peserta didik kelas VIII SMP IT Nurul Huda Keerom, hanya sebagian kecil yang mendapat nilai di atas standar penilaian.

Hasil wawancara terbatas kepada Bapak Muhammad Qomaruddin, M.Pd selaku guru mata pelajaran matematika di SMP IT Nurul Huda Keerom menyatakan bahwa, hasil belajar peserta didik kelas VIII SMP IT Nurul Huda Keerom sebagian besar masih dibawah standar nilai KKM. Hal ini dapat diindikasikan karena pemahaman konsep peserta didik terkait materi tersebut masih kurang. Tetapi tidak semua peserta didik mendapatkan nilai yang kurang memuaskan, ada beberapa peserta didik yang memenuhi standar nilai KKM, dan ada juga peserta didik yang memiliki nilai lebih bagus. Dari hasil belajar peserta didik tersebut, terbukti bahwa terdapat perbedaan kemampuan dan 
pemahaman matematika di setiap peserta didik. Karena alasan tersebut, peneliti bermaksud menganalisis tingkat pemahaman konsep peserta didik pada materi segitiga terkait keliling dan luas segitiga. Penelitian ini perlu dilakukan karena apabila peserta didik kurang memahami konsep keliling dan luas segitiga, maka akan berpengaruh terhadap pemahaman konsep materi selanjutnya. Pemahaman konsep keliling dan luas segitiga perlu dimiliki oleh peserta didik. Hal ini karena pemahaman tersebut dapat digunakan dalam menyelesaikan masalah kehidupan sehari-hari yang berkaitan dengan segitiga.

\section{METODE}

Penelitian ini termasuk jenis penelitian deskriptif kualitatif. Penelitian deskriptif itu sendiri bertujuan untuk mendeskripsikan satu obyek, fenomena, atau setting sosial yang akan dituangkan dalam tulisan yang bersifat naratif. Arti dalam penulisannya data dan fakta yang dihimpun berbentuk kata atau gambar daripada angka. Dalam penulisan laporan penelitian kualitatif berisi kutipan-kutipan data (fakta) yang diungkap di lapangan untuk memberikan dukungan terhadap apa yang disajikan dalam laporannyA (Albi Anggito dan Johan Setiawan, 2018, p. 11). Deskripsi penelitian yaitu peserta didik kelas VIII SMP IT Nurul Huda Keerom akan dibagi menjadi tiga kategori berdasarkan tingkat kemampuan matematika peserta didik yaitu peserta didik berkemampuan tinggi, sedang, dan rendah. Setelah terbagi menjadi tiga kategori, maka peneliti akan mengambil dua subjek dari ketiga kategori tersebut. Selanjutnya peneliti akan menjelaskan tingkat pemahaman konsep keliling dan luas segitiga satu subjek dari masing-masing kategori berdasarkan hasil tes pemahaman konsep keliling dan luas segitiga dan wawancara.

Penelitian ini dilakukan di SMP IT Nurul Huda Keerom yang beralamat di Jalan kasuari, Arso II, Kabupaten Keerom, Papua. Penelitian dilakukan di kelas VIII pada semester genap tahun ajaran 2019/2020. Pendekatan penelitian yang dimaksud dalam penelitian ini yaitu pendekatan studi atau keilmuan. Pendekatan tersebut digunakan untuk menjelaskan perspektif peneliti dalam pembahasan objek penelitian.

Sumber data penelitian ini adalah peserta didik kelas VIII SMP IT Nurul Huda Keerom tahun ajaran 2019/2020. Peneliti mendapatkan subjek dengan cara melakukan tes kemampuan matematika pada peserta didik kelas VIII SMP IT Nurul Huda Keerom. Hasil dari tes kemampuan tersebut akan membagi peserta didik kelas VIII SMP IT Nurul Huda Keerom menjadi tiga kategori berdasarkan tingkat kemampuan yaitu peserta didik dengan kemampuan tinggi, sedang dan rendah. Setelah peserta didik kelas VIII dikelompokkan menjadi tiga kategori, selanjutnya peneliti akan mendiskusikan kepada wali kelas VIII untuk mengambil satu subyek dari setiap ketiga kategori kemampuan tersebut. Setelah didapatkan satu subyek dari masing-masing kategori, peneliti akan memberikan tes pemahaman konsep keliling dan luas segitiga dan wawancara kepada semua subyek.

Metode penelitian yang digunakan yaitu Wawancara, Tes, dan Dokumen. Wawancara digunakan sebagai teknik pengumpulan data apabila ingin melakukan studi pendahuluan untuk menemukan permasalahan yang harus diteliti, dan juga apabila peneliti ingin mengetahui hal-hal dari responden yang lebih mendalam dan jumlah respondennya sedikit atau kecil (Sugiyono, 2017, p.137). Pengumpulan data melalui teknik tes dilakukan dengan memberikan instrumen yang terdiri dari seperangkat pertanyaan/soal untuk memperoleh data mengenai kemampuan peserta didik terutama pada aspek 
kognitif. Instrumen tes yang diberikan dapat berupa tes kemampuan, seperti tes IQ, tes hasil belajar, atau tes untuk mengukur kemampuan tertentu, seperti tes kemampuan pemahaman konsep matematis, tes kemampuan komunikasi matematis, dan tes kemampuan matematis (Karunia Eka Lestari dan Mokhammad Ridwan, 2018, p.232).

Instrumen inti dalam penelitian ini yaitu penelliti sendiri sedangkan instrumen bantuan diantaranya instrumen tes dimana tes terdapat dua yaitu tes kemampuan dan tes pemahaman konsep dan pedoman wawancara.

\section{HASIL}

Hal yang pertama untuk menjawab rumusan masalah yaitu Pemahaman Konsep Keliling dan Luas Segitiga Peserta Didik Kelas VIII SMP IT Nurul Huda Keerom Berdasarkan Taksonomi Bloom, berikut penjelasannya.

\section{Subjek berkemampuan matematika tinggi (ST)}

Subjek berkemampuan matematika tinggi (ST) berjumlah 1 orang. Subjek tersebut dipilih berdasarkan hasil tes kemampuan matematika. Selanjutnya subjek diberikan instrumen tes pemahaman konsep keliling dan luas segitiga. Dari 8 soal tes pemahaman konsep keliling dan luas segitiga, ST hanya mampu menyelesaikan 6 soal, yaitu soal nomor 1 sampai dengan soal nomor 6 .

Pada soal nomor (1) ST hanya mampu menjawab 4 segitiga yaitu segitiga sama kaki, sama sisi, siku-siku, dan segitiga sembarang. Berdasarkan jawaban yang tepat, ada dua jenis segitiga yang tidak disebutkan oleh ST, yaitu segitiga tumpul dan segitiga lancip. ST tidak mampu mengklasifikasikan jenis segitiga yang disebutkan.

Pada soal nomor (2), ST mampu menjawab dengan sempurna berdasarkan dari jawaban soal nomor satunya. Berdasarkan hasil wawancara pada soal nomor 2, ST tidak mengalami kesulitan dalam menjawab soal nomor 2. ST menjawab Segitiga siku-siku yaitu segitiga yang besar salah satu sudutnya yaitu 90 derajat. Segitiga sembarang yaitu segitiga yang semua panjang sisinya berbeda-beda. Segitiga sama sisi yaitu segitiga yang panjang sisinya sama semua. Dan segitiga sama kaki yaitu segitiga yang dua sisinya sama panjang.

Pada soal nomor (3), ST mampu menjawab dengan benar. Tetapi tidak ada keterangan tentang simbol-simbol yang di tulis oleh subyek. Berdasarkan hasil wawancara ST mampu menyebutkan rumus keliling yaitu keliling segitiga adalah a $+\mathrm{b}+\mathrm{c}$. ST juga mampu menjawab menyebutkan rumus luas dari segitiga yaitu $\frac{1}{2} \times$ $\mathrm{a} \times \mathrm{t}$. Pada pertanyaan peneliti tentang simbol-simbol yang ditulis oleh ST, ST menjawab bahwa pada rumus keliling $\mathrm{a}, \mathrm{b}$ dan $\mathrm{c}$ merupakan sisi-sisi dari segitiga, sedangkan untuk rumus dari luas a merupakan alas dan t merupakan tinggi.

Pada soal nomor 4, ST mampu menjawab dengan benar, baik itu keliling dan luas. Peneliti ingin mengetahui lebih lanjut bagaimana proses kerja ST dalam menjelaskan soal nomor 4 melalui wawancara dan hasil wawancara. Berdasarkan hasil wawancara, ST mengetahui panjang dari sisi-sisi segitiga. ST mampu menjawab penyelesaian dari keliling, karena ST melihat dari ketiga sisi segitiga terdapat 3 angka, sehingga ST langsung menjumlahkan ketiga angka tersebut untuk mencari keliling dari segitiga. Selanjutnya ST menjawab luas dari segitiga dengan menentukan alas dan tinggi dari segitiga. ST menentukan alas dari segitiga yaitu 15 $\mathrm{cm}$ dan tinggi yaitu $20 \mathrm{~cm}$.

Pada soal nomor 5, ST menjawab semuanya baik itu keliling maupun luas segitiga. Tetapi, jawaban yang diberikan ST salah, sehingga peneliti mengkaji lebih lanjut 
melalui wawancara. Berdasarkan hasil wawancara, ST bingung dalam menentukan sisi-sisi dari segitiga. ST juga tidak dapat menentukan alas dan tinggi dari segitiga. Sehingga dalam menjawab keliling dan luas segitiga ST hanya menjawab semampunya.

Pada soal nomor 6, subjek tidak mampu menyelesaikan jawabannya. Subjek hanya mampu menggambar segitiga dan tidak menyelesaikannya. Melihat jawaban subjek, peneliti ingin mengetahui lebih lanjut jawaban subjek melalui wawancara. Berdasarkan hasil wawancara, ST hanya mengetahui panjang sisi-sisi dari taman dan harga setiap bibitnya. Untuk selanjutnya ST tidak dapat menjawab karena masih bingung dalam menggunakan rumus segitiga.

\section{Subjek Berkemampuan Matematika Sedang (SS)}

Subjek berkemampuan matematika sedang (SS) berjumlah 1 orang. Subjek tersebut dipilih berdasarkan hasil tes kemampuan matematika. Selanjutnya subjek diberikan instrumen tes pemahaman konsep keliling dan luas segitiga. Dari 8 soal tes pemahaman konsep keliling dan luas segitiga, SS hanya mampu menyelesaikan 5 soal, yaitu soal nomor 1 sampai dengan soal nomor 5 .

Pada nomor 1, SS mampu menjawab soal dengan benar. Semua segitiga disebutkan walaupun tidak dapat mengklasifikasikan jenis segitiganya. Berdasarkan hasil wawancara, subyek hanya dapat mengingat semua segitiga tanpa mampu mengklasifikasikan jenisnya.

Pada soal nomor 2, SS mampu menjawab soal dengan lengkap dan benar. Semua segitiga yang dijawab pada nomor satu, mampu dideskripsikan oleh SS. Untuk mengkaji lebih dalam terkait jawaban yang diberikan oleh SS, peneliti melakukan wawancara,. Berdasarkan hasil wawancara, SS dengan sempurna mendefinisikan jenis-jenis segitiga yang telah disebutkan pada soal nomor 1. SS menjawab segitiga lancip yaitu segitiga yang besar sudutnya di bawah 90 derajat. Segitiga siku-siku yaitu segitiga yang salah satu sudutnya 90 derajat. Segitiga tumpul yang salah satu sudutnya lebih dari 90 derajat. Segitiga sama kaki yaitu segitiga yang memiliki dua sisi yang sama panjang. Segitiga sama sisi yaitu segitiga yang semua sisinya sama panjang. Dan segitiga sembarang yaitu segitiga yang panjang sisi-sisinya berbeda.

Pada soal nomor 3, SS mampu menjawab dengan benar. Tetapi, SS hanya menulis rumusnya tanpa keterangan dari simbol-simbol yang ditulis. Peneliti mengkaji lebih lanjut terkait jawaban yang diberikan oleh SS melalui wawancara. Berdasarkan hasil wawancara, SS mampu menyebutkan rumus dari keliling dan luas segitiga. SS juga mampu mengartikan simbol yang ditulis. Simbol dari keliling yaitu a, b dan c merupakan sisi-sisi dari segitiga, sedangkan simbol dari luas yaitu a adalah alas, dan $\mathrm{t}$ adalah tinggi.

Pada soal nomor 4, SS menjawab soal dengan benar baik itu keliling segitiga maupun luas segitiga. Tetapi jawaban SS masih kurang lengkap yaitu penulisan $\mathrm{cm}^{2}$ pada soal luas segitiga. Selanjutnya peneliti mengkaji lebih lanjut jawaban SS melalui wawancara. Berdasarkan hasil wawancara, SS mengetahui panjang dari setiap sisi-sisi segitiga. SS menjawab keliling segitiga dengan menjumlahkan semua sisi-sisi segitiga yang ada. Pada jawaban mencari luas, SS menentukan alas dan tingginya dengan hanya memperkirakan. Ini membuktikan bahwa SS masih belum memahami alas dan tinggi dari segitiga.

Pada soal nomor 5, SS mampu menjawab soal, namun dari jawaban yang diberikan hanya sebagian jawaban yang benar. SS mampu menjawab soal tentang keliling segitiga dengan benar. Pada soal tentang luas segitiga, SS mencoba menjawab soal 
tersebut dengan lengkap, namun sebagian jawaban yang diberikan belum benar. Untuk mengkaji lebih dalam mengenai jawaban SS, peneliti melakukan wawancara. Berdasarkan hasil wawancara, dalam menjawab keliling segitiga SS menjumlahkan semua sisi-sisi segitiga. Sedangkan untuk menjawab luas SS masih bingung menentukan alas dan tinggi dari segitiga.

\section{Subyek Berkemampuan Matematika Rendah (SR)}

Subjek berkemampuan matematika rendah (SR) berjumlah 1 orang. Subjek tersebut dipilih berdasarkan hasil tes kemampuan matematika. Selanjutnya subjek diberikan instrumen tes pemahaman konsep keliling dan luas segitiga. Dari 8 soal tes pemahaman konsep keliling dan luas segitiga, SR hanya mampu menyelesaikan 4 soal, yaitu soal nomor 1 sampai dengan soal nomor 4 .

Pada soal nomor 1, SS hanya mampu menjawab satu segitiga yaitu segitiga sikusiku. Peneliti pun mengkaji lebih dalam jawaban dari subyek melalui wawancara. Berdasarkan hasil wawancara, ternyata SR hanya mengetahui satu segitiga yaitu segitiga siku-siku karena SR hanya mengingat segitiga tersebut. SR tidak dapat menjawab segitiga lainnya yaitu segitiga lancip, segitiga tumpul, segitiga sebarang, segitiga sama sisi dan segitiga sama kaki.

Pada soal nomor 2, SR mampu menjawab dengan baik karena hanya menjawab satu segitiga yaitu segitiga siku-siku. Berdasarkan hasil wawancara, SR mampu menjawab definisi dari segitiga yang dijawab pada soal nomor 1 . SR menjawab segitiga siku-siku adalah segitiga yang salah satu sudutnya adalah 90 derajat.

Pada soal nomor 3, SR mampu menjawab dengan benar walaupun tanpa keterangan dari masing-masing simbol yang ditulis. Berdasarkan hasil wawancara, SR mampu menulis rumus keliling dan luas dari segitiga. Rumus keliling dan luas segitiga dijawab dengan benar dan menggunakan simbol. Ketika peneliti menanyakan tentang simbol yang ditulis oleh SR, SR tidak mampu menjawabnya. SR hanya menghafal rumus tanpa mengetahui arti dari simbol yang ditulis.

Pada soal nomor 4, SR hanya mampu menjawab soal tentang keliling segitiga. SR tidak mampu menjawab soal tentang luas. Peneliti pun mengkaji lebih lanjut jawaban SR melalui wawancara. Berdasarkan hasil wawancara, SR mampu menjawab soal tentang keliling segitiga. Tetapi jawaban yang diberikan oleh SR kurang tepat. Karena SR masih bingung dalam menentukan sisi-sisi mana yang digunakan untuk mendapat keliling segitiga. Dalam menentukan luas, SR masih bingung untuk menentukan alas dan tinggi dari segitiga, sehingga SR tidak dapat menjawab luas dari segitiga.

Selanjutnya untuk menjawab rumusan masalah yang kedua yaitu Faktor-Faktor Yang Mempengaruhi Pemahaman Konsep Keliling dan Luas Segitiga Peserta Didik Kelas VIII SMP IT Nurul Huda Keerom.

\section{Subjek Berkemampuan Matematika Tinggi}

Ada beberapa faktor yang mempengaruhi subjek berkemampuan matematika tinggi pada pemahaman konsepnya. Berdasarkan hasil wawancara peneliti terkait faktorfaktor yang mempengaruhi pemahaman konsep peserta didik khususnya di materi keliling dan luas segitiga, ST selalu kesiapan setiap pelajaran akan dimulai. Tetapi ST memiliki sedikit minat dalam belajar matematika.

Pada lingkungan keluarga, ST menjawab bahwa orang tua ST selalu memberikan motivasi dengan cara selalu diingatkan belajar. Pada lingkungan sekolah, ST 
mengatakan bahwa di Sekolah terdapat fasilitas buku untuk memudahkan belajar materi keliling dan luas segitiga. ST juga mengatakan bahwa guru matematika di Sekolah selalu memberikan motivasi dalam belajar.

\section{Subjek Berkemampuan Matematika Sedang}

Ada beberapa faktor yang mempengaruhi peserta didik yang berkemampuan sedang pada pemahaman konsepnya. Berdasarkan hasil wawancara, SS selalu memiliki kesiapan dalam memulai pelajaran. SS memiliki sedikit minat dalam belajar matematika khususnya materi keliling dan luas segitiga. SS juga mengaku tidak memiliki bakat dalam belajar.

Pada lingkungan keluarga, orang tua SR selalu memberi dukungan SS untuk selalu belajar. Pada lingkungan sekolah, SS diberikan fasilitas untuk belajar berupa buku paket sehingga memudahkan SS untuk memahami materi matematika khususnya keliling dan luas segitiga. SS juga selalu diberi motivasi oleh guru matematika SMP IT Nurul Huda Keerom.

\section{Subjek Berkemampuan Matematika Rendah}

Ada beberapa faktor yang mempengaruhi subjek yang berkemampuan matematika rendah pada pemahaman konsepnya. Berdasarkan hasil wawancara, maka ada dua faktor yang mempengaruhi pemahaman konsep belajar SR. Faktor yang pertama yaitu faktor internal, yang terdiri dari kesiapan dan bakat SR. SR selalu siap dalam melakukan pembelajaran. SR tidak memiliki bakat, tetapi SR selalu mencoba untuk memahami materi keliling dan luas segitiga. SR mempunyai motivasi dari diri sendiri yang kuat untuk memahami materi keliling dan luas segitiga.

Faktor kedua yaitu faktor eksternal yang terdiri dari pengaruh dari orang tua, sekolah, dan lingkungan. SR selalu diingatkan oleh orang tuanya untuk selalu tekun dalam belajar. SR juga dapat memahami materi segitiga keliling dan luas karena mendapat fasilitas dari sekolah seperti buku. SR juga selalu diberi motivasi oleh gurunya untuk selalu semangat dalam belajar.

\section{PEMBAHASAN}

Dari hasil penelitian tersebut selanjutnya dibahas sesuai dengan teori penelitian ini yaitu Taksonomi Bloom. Hal yang pertama dibahas yaitu Pemahaman Konsep Keliling Dan Luas Segitiga Peserta Didik Kelas VIII SMP IT Nurul Huda Keerom Berdasarkan Taksonomi Bloom

\section{Subjek Berkemampuan Matematika Tinggi (ST)}

Berdasarkan hasil tes pemahaman peserta didik yang dilakukan oleh peneliti, ST mampu menjawab 6 soal dari 8 soal tes pemahaman konsep keliling dan luas segitiga yang diberikan. Pada soal nomor 1, ST tidak mampu menjawab dengan lengkap, karena masih ada dua segitiga yang belum disebutkan. Pada soal nomor 2, ST mampu menjawab dengan benar dan lengkap. Pada soal nomor 3, SR juga mampu menjawab soal dengan benar. Pada soal nomor 4, ST dapat menjawab soal dengan benar. Pada soal nomor 5, ST mampu menjawab soal tetapi tidak benar. Pada soal nomor 6, ST tidak dapat menjawab soal dengan lengkap sehingga jawaban yang diberikan salah. Soal nomor 7 dan 8 , ST tidak dapat menjawabnya karena merasa kesulitan. Dari 6 soal yang dijawab oleh ST, hanya 4 soal yang dijawab dengan benar dan 2 soal lainnya masih salah. 
Berdasarkan indikator yang telah dibuat oleh peneliti terkait pemahaman konsep keliling dan luas segitiga berdasarkan Taksonomi Bloom, setiap nomor soal yang diberikan kepada ST memuat tahapan kognitif Taksonomi Bloom. Tahap mengingat termuat pada soal nomor 1 dan 3. Apabila ST mampu menjawab soal nomor 1 dan 3 maka ST berada pada tahap mengingat. Pada tes pemahaman konsep keliling dan luas segitiga, ST mampu menjawab soal nomor 1 dan 3 dengan benar walaupun masih kurang lengkap dengan jawaban yang diberikan, tetapi ST tetap berada pada tahap mengingat. Selanjutnya tahap memahami termuat pada soal nomor 2. ST mampu menjawab soal nomor 2 dengan benar sehingga level ST sampai pada tahap memahami. Selanjutnya tahap mengaplikasikan termuat pada soal nomor 4 dan 5 . ST mampu menjawab soal nomor 4 dengan benar sehingga ST sampai pada tahap mengaplikasikan. ST tidak mampu menjawab soal nomor 5 dan 6 dengan benar, sehingga ST tidak mampu sampai ke tahap menganalisis. Tahapan selanjutnya yaitu tahap mengevaluasi yang termuat pada soal nomor 7 dan tahap mencipta yang termuat pada soal nomor 8. ST tidak mampu menjawab soal nomor 7 dan 8 , sehingga ST tidak mampu berlanjut ke tahapan mengevaluasi dan mencipta.

Berdasarkan hasil analisis jawaban dan wawancara kepada ST, dapat disimpulkan berdasarkan Taksonomi Bloom bahwa ST berada pada tahap mengaplikasikan. Hal ini dikarenakan ST hanya mampu menjawab soal nomor 1 sampai nomor 4 dengan benar. Tahap mengingat dalam Taksonomi Bloom ditandai dengan kemampuan mengenali dan memanggil kembali. ST mampu melewati tahap mengingat, dimana ST mampu memanggil kembali informasi yang sudah di simpan dalam ingatannya dengan menyebutkan jenis segitiga dan rumus keliling dan luas segitiga. Tahap memahami dalam Taksonomi Bloom ditandai dengan kemampuan mengklasifikasikan dan membandingkan. ST mampu melewati tahap memahami karena ST dapat mengklasifikasikan dan membandingkan serta menjelaskan jenisjenis segitiga yang ada. Selanjutnya tahap mengaplikasikan dalam Taksonomi Bloom ditandai dengan kemampuan memanfaatkan atau mempergunakan suatu prosedur untuk melaksanakan percobaan atau menyelesaikan permasalahan. Dalam hal ini, ST mampu menggunakan rumus keliling dan luas segitiga dengan benar untuk mendapatkan jawaban pada soal yang dikerjakan.

Tahap menganalisis dalam Taksonomi Bloom ditandai dengan kemampuan memecahkan suatu permasalahan dengan memisahkan tiap-tiap bagian dari permasalahan dalam mencari keterkaitan dari tiap-tiap bagian tersebut dan mencari tahu bagaimana keterkaitan tersebut dapat menimbulkan masalah. Dalam hal ini, ST mampu menggunakan rumus keliling dan luas segitiga, tetapi ketika diberikan soal yang lebih rumit, ST tidak mampu menjawabnya. Sehingga ST hanya dapat mengerjakan soal sampai pada tahap mengaplikasikan. Jadi dapat disimpulkan bahwa pemahaman konsep keliling dan luas segitiga ST sampai pada tahap mengaplikasikan. Selanjutnya terdapat beberapa kesulitan subjek dalam menjawab soal, diantaranya kurang pemahaman dalam menentukan alas dan tinggi dari sebuah segitiga.

\section{Subjek Berkemampuan Matematika Sedang (SS)}

Berdasarkan hasil analisis tes pemahaman konsep keliling dan luas segitiga yang dilakukan peneliti, SS mampu menjawab 5 soal dari 8 soal tes pemahaman konsep keliling dan luas segitiga yang diberikan. Pada soal nomor 1, SS mampu menjawab dengan lengkap dan benar. Pada soal nomor dua, SS mampu menjawab dengan 
benar. Pada soal nomor 3, SS juga mampu menjawab soal dengan benar. Pada soal nomor 4, SS dapat menjawab soal dengan benar. Pada soal nomor 5, SS mampu menjawab soal tetapi tidak benar semua. Soal nomor 6, 7 dan 8, SS tidak dapat menjawabnya karena merasa kesulitan. Dari 5 soal yang dijawab oleh SS, hanya 4 soal yang dijawab dengan benar dan 1 soal lainnya masih salah.

Berdasarkan indikator yang telah dibuat oleh peneliti terkait pemahaman konsep keliling dan luas segitiga berdasarkan Taksonomi Bloom, setiap nomor soal yang diberikan kepada SS memuat tahapan kognitif Taksonomi Bloom. Tahap mengingat termuat pada soal nomor 1 dan 3. Apabila SS mampu menjawab soal nomor 1 dan 3 maka SS berada pada tahap mengingat. Pada tes pemahaman konsep keliling dan luas segitiga, SS mampu menjawab soal nomor 1 dan 3 dengan benar walaupun masih kurang lengkap dengan jawaban yang diberikan, tetapi ST tetap berada pada tahap mengingat. Selanjutnya tahap memahami termuat pada soal nomor 2. SS mampu menjawab soal nomor 2 dengan benar sehingga level SS sampai pada tahap memahami. Selanjutnya tahap mengaplikasikan termuat pada soal nomor 4 dan 5 . SS mampu menjawab soal nomor 4 dan 5 dengan benar sehingga SS sampai pada tahap mengaplikasikan. SS tidak mampu menjawab soal nomor 6 yang memuat tahapan menganalisis, sehingga SS tidak mampu sampai ke tahap menganalisis. Tahapan selanjutnya yaitu tahap mengevaluasi yang termuat pada soal nomor 7 dan tahap mencipta yang termuat pada soal nomor 8. SS tidak mampu menjawab soal nomor 7 dan 8 , sehingga SS tidak mampu berlanjut ke tahapan mengevaluasi dan mencipta.

Berdasarkan hasil analisis jawaban dan wawancara kepada SS, dapat disimpulkan berdasarkan Taksonomi Bloom bahwa SS berada pada tahap mengaplikasikan. Hal ini dikarenakan SS hanya mampu menjawab soal nomor 1 sampai nomor 5 dengan benar. Tahap mengingat dalam Taksonomi Bloom ditandai dengan kemampuan mengenali dan memanggil kembali. SS mampu melewati tahap mengingat, dimana SS mampu memanggil kembali informasi yang sudah di simpan dalam ingatannya dengan menyebutkan jenis segitiga dan rumus keliling dan luas segitiga. Tahap memahami dalam Taksonomi Bloom ditandai dengan kemampuan mengklasifikasikan dan membandingkan. SS mampu melewati tahap memahami karena SS dapat mengklasifikasikan dan membandingkan serta menjelaskan jenisjenis segitiga yang ada. Selanjutnya tahap mengaplikasikan dalam Taksonomi Bloom ditandai dengan kemampuan memanfaatkan atau mempergunakan suatu prosedur untuk melaksanakan percobaan atau menyelesaikan permasalahan. Dalam hal ini, SS mampu menggunakan rumus keliling dan luas segitiga dengan benar untuk mendapatkan jawaban pada soal yang dikerjakan.

Tahap menganalisis dalam Taksonomi Bloom ditandai dengan kemampuan memecahkan suatu permasalahan dengan memisahkan tiap-tiap bagian dari permasalahan dalam mencari keterkaitan dari tiap-tiap bagian tersebut dan mencari tahu bagaimana keterkaitan tersebut dapat menimbulkan masalah. Dalam hal ini, SS mampu menggunakan rumus keliling dan luas segitiga, tetapi ketika diberikan soal yang lebih rumit, SS tidak mampu menjawabnya. Sehingga SS hanya dapat mengerjakan soal sampai pada tahap mengaplikasikan. Jadi dapat disimpulkan bahwa pemahaman konsep keliling dan luas segitiga SS sampai pada tahap mengaplikasikan. Selanjutnya terdapat beberapa kendala dalam mengerjakan tes pemahaman konsep keliling dan luas segitiga diantaranya, SS tidak memahami betul menentukan alas dan tinggi dari sebuah segitiga. 


\section{Subjek Berkemampuan Matematika Rendah (SR)}

Berdasarkan hasil analisis tes pemahaman konsep keliling dan luas segitiga yang dilakukan oleh peneliti, SR mampu menjawab 4 soal dari 8 soal tes pemahaman konsep keliling dan luas segitiga yang diberikan. Pada soal nomor 1, SR tidak mampu menjawab dengan lengkap, SR hanya menjawab satu jenis segitiga dari enam jenis segitiga. Pada soal nomor dua, SR mampu menjawab dengan benar. Pada soal nomor 3, SR juga mampu menjawab soal dengan benar. Pada soal nomor 4, SR dapat menjawab soal tetapi jawaban yang diberikan tidak semuanya benar. Soal nomor 5, 6, 7 dan 8 SR tidak mampu menjawabnya karena merasa kesulitan. Dari 4 soal yang dijawab oleh SR, hanya 3 soal yang dijawab dengan benar dan 1 soal masih kurang lengkap jawabannya.

Berdasarkan indikator yang telah dibuat oleh peneliti terkait pemahaman konsep keliling dan luas segitiga berdasarkan Taksonomi Bloom, setiap nomor soal yang diberikan kepada SR memuat tahapan kognitif Taksonomi Bloom. Tahap mengingat termuat pada soal nomor 1 dan 3. Apabila SR mampu menjawab soal nomor 1 dan 3 maka SR berada pada tahap mengingat. Pada tes pemahaman konsep keliling dan luas segitiga, SR mampu menjawab soal nomor 1 dan 3 dengan benar walaupun masih kurang lengkap dengan jawaban yang diberikan, tetapi SR tetap berada pada tahap mengingat. Selanjutnya tahap memahami termuat pada soal nomor 2. SR mampu menjawab soal nomor 2 dengan benar sehingga level SR sampai pada tahap memahami. Selanjutnya tahap mengaplikasikan termuat pada soal nomor 4 dan 5 . SR tidak mampu menjawab soal nomor 4 dan 5 sehingga ST tidak mampu berlanjut pada tahap mengaplikasikan. ST juga tidak mampu menjawab soal nomor 6, 7 dan 8 yang memuat tahapan menganalisis, mengevaluasi, dan mencipta. Sehingga SR tidak mampu berlanjut sampai pada tahap mencipta.

Berdasarkan hasil analisis jawaban dan wawancara kepada SR, dapat disimpulkan berdasarkan Taksonomi Bloom bahwa SR berada pada tahap memahami. Hal ini dikarenakan SR hanya mampu menjawab soal nomor 1 sampai nomor 3 dengan benar. Tahap mengingat dalam Taksonomi Bloom ditandai dengan kemampuan mengenali dan memanggil kembali. SR mampu melewati tahap mengingat, dimana SR mampu memanggil kembali informasi yang sudah di simpan dalam ingatannya dengan menyebutkan jenis segitiga dan rumus keliling dan luas segitiga. Tahap memahami dalam Taksonomi Bloom ditandai dengan kemampuan mengklasifikasikan dan membandingkan. SR mampu sampai pada tahap memahami karena SR dapat mengklasifikasikan dan membandingkan serta menjelaskan jenisjenis segitiga yang ada. Selanjutnya tahap mengaplikasikan dalam Taksonomi Bloom ditandai dengan kemampuan memanfaatkan atau mempergunakan suatu prosedur untuk melaksanakan percobaan atau menyelesaikan permasalahan. Dalam hal ini, SR tidak mampu menggunakan rumus keliling dan luas segitiga dengan benar untuk mendapatkan jawaban pada soal yang dikerjakan. Sehingga SR tidak dapat berlanjut ke tahap mengaplikasikan.

Jadi dapat disimpulkan bahwa pemahaman konsep keliling dan luas segitiga SR hanya sampai pada tahap memahami. Terdapat beberapa kesulitan SR dalam menjawab soal, diantaranya SR masih ragu dalam menentukan alas dan tinggi dari sebuah segitiga. SR juga tidak mampu menjelaskan dengan baik pengertian dari simbol-simbol segitiga baik rumus luas maupun keliling. SR juga tidak mengetahui dengan betul jenis-jenis segitiga, sehingga untuk mengerjakan soal selanjutnya akan mengalami sedikit kesulitan. 
Selanjutnya pembahasan tentang Faktor-Faktor Yang Mempengaruhi Pemahaman Konsep Keliling dan Luas Segitiga Peserta Didik Kelas VIII SMP IT Keerom

\section{Subjek Berkemampuan Matematika Tinggi (ST)}

Berdasarkan hasil wawancara tentang faktor yang mempengaruhi belajar matematika. Secara internal ST memiliki kesiapan dalam setiap pembelajaran. Kesiapan dalam belajar adalah kondisi awal peserta didik yang siap dalam melakukan suatu kegiatan belajar baik dalam arti siap fisik, psikis, dan materi. Dalam hal ini, ST selalu memiliki kesiapan dalam memulai pelajaran matematika dikarenakan ST mempunyai kondisi tubuh yang fit dan sehat. Selain itu, ST juga selalu membawa perlengkapan belajar sehingga ST selalu siap ketika pelajaran dimulai. Selain kesiapan belajar, ST ternyata memiliki sedikit minat untuk belajar matematika khususnya materi keliling dan luas segitiga. Hal ini disebabkan ST belum memahami secara baik materi keliling dan luas segitiga.

Secara eksternal, SR selalu dimotivasi oleh orang tuanya untuk rajin dalam belajar. Motivasi sangat dibutuhkan peserta didik karena motivasi dapat mendorong semangat peserta didik dalam belajar. Motivasi yang diberikan orang tua kepada ST yaitu dalam bentuk perhatian untuk lebih semangat lagi dalam belajar. Dalam lingkup sekolah, ST mendapatkan fasilitas buku agar lebih mudah dalam memahami materi keliling dan luas segitiga. Buku sangat penting dalam aktivitas belajar, dikarenakan buku dapat memudahkan ST lebih mudah memahami setiap materi yang dipelajari khususnya materi keliling dan luas segitiga. ST juga sering diberi motivasi oleh guru matematika SMP IT Nurul Huda Keerom.

\section{Subjek Berkemampuan Matematika Sedang (SS)}

Berdasarkan hasil wawancara tentang faktor yang mempengaruhi belajar matematika. Secara internal SS memiliki kesiapan dalam belajar. Kesiapan dalam belajar adalah kondisi awal peserta didik yang siap dalam melakukan suatu kegiatan belajar baik dalam arti siap fisik, psikis, dan materi. Dalam hal ini, SS selalu memiliki kesiapan dalam memulai pelajaran matematika dikarenakan SS mempunyai kondisi tubuh yang fit dan sehat. Selain itu, SS juga selalu membawa perlengkapan belajar sehingga SS selalu siap ketika pelajaran dimulai. Berbeda dengan ST, SS memiliki minta belajar pada keliling dan luas segitiga. Hal ini disebabkan karena keingintahuan SS dalam memahami materi keliling dan luas segitiga.

Secara eksternal, SS selalu didukung oleh orang tuanya untuk rajin dalam belajar. Dukungan tersebut merupakan motivasi untuk SS dalam belajar. Motivasi sangat dibutuhkan peserta didik karena motivasi dapat mendorong semangat peserta didik dalam belajar. Dalam lingkup sekolah, SS mendapatkan fasilitas buku agar lebih mudah dalam memahami materi keliling dan luas segitiga. Buku sangat penting dalam aktivitas belajar, dikarenakan buku dapat memudahkan SS lebih mudah memahami setiap materi yang dipelajari khususnya materi keliling dan luas segitiga. SS juga sering diberi motivasi oleh guru matematika SMP IT Nurul Huda Keerom.

\section{Subjek Berkemampuan Matematika Rendah (SR)}

Berdasarkan hasil wawancara tentang faktor yang mempengaruhi belajar matematika. Secara internal SR memiliki kesiapan dalam belajar. Kesiapan dalam belajar adalah kondisi awal peserta didik yang siap dalam melakukan suatu kegiatan 
belajar baik dalam arti siap fisik, matematika dikarenakan SS mempunyai kondisi tubuh yang fit dan sehat. Berbeda dengan ST dan SS, SR memiliki motivasi diri sendiri karena merasa tidak memiliki bakat. Motivasi tersebut membuat SR lebih giat dalam belajar.

Secara eksternal, SR selalu diingatkan oleh orang tuanya untuk rajin dalam belajar. Dukungan tersebut merupakan motivasi untuk SR dalam belajar. Motivasi sangat dibutuhkan peserta didik karena motivasi dapat mendorong semangat peserta didik dalam belajar. Dalam lingkup sekolah, SR mendapatkan fasilitas buku agar lebih mudah dalam memahami materi keliling dan luas segitiga. Buku sangat penting dalam aktivitas belajar, dikarenakan buku dapat memudahkan SSRlebih mudah memahami setiap materi yang dipelajari khususnya materi keliling dan luas segitiga. SR juga sering diberi motivasi oleh guru matematika SMP IT Nurul Huda Keerom.

\section{KESIMPULAN}

Berdasarkan penyajian data dan pembahasan peneliti mengenai Analisis Pemahaman Konsep Keliling dan Luas Segitiga Peserta Didik Kelas VIII SMP IT Nurul Huda Keerom Berdasarkan Taksonomi Bloom, maka diperoleh kesimpulan sebagai berikut: Berdasarkan teori Taksonomi Bloom, subjek berkemampuan tinggi berada pada level mengaplikasikan. Subjek berkemampuan sedang berada pada level mengaplikasikan. Subjek yang berkemampuan rendah berada pada level memahami. Faktor Internal dan Eksternal yang mempengaruhi pemahaman konsep keliling dan luas segitiga peserta didik kelas VIII SMP IT Nurul Huda Keerom berdasarkan Taksonomi Bloom, adalah Subjek berkemampuan matematika tinggi memiliki kesiapan dalam belajar. Subjek berkemampuan matematika tinggi juga memiliki sedikit minat untuk belajar materi keliling dan luas segitiga. Subjek berkemampuan matematika sedang memiliki kesiapan juga dalam belajar. Subjek berkemampuan matematika sedang memiliki minat untuk belajar, tetapi merasakan tidak mempunyai bakat. Subjek berkemampuan matematika rendah selalu memiliki kesiapan dalam belajar. Subjek berkemampuan matematika rendah mempunyai motivasi dari diri sendiri untuk belajar, karena subjek mengakui tidak memiliki bakat tetapi selalu berusaha untuk memahami materi keliling dan luas segitiga. Sedangkan faktor eksternalnya yaitu semua subjek baik yang berkemampuan matematika tinggi, sedang dan rendah, mendapat motivasi dari keluarga dalam belajar. Ada yang selalu diingatkan belajar, dan ada yang selalu diberi motivasi untuk selalu rajin belajar. Pada lingkungan sekolah, semua subjek mendapatkan fasilitas buku, dan juga selalu diberi motivasi oleh guru matematikanya.

\section{DAFTAR PUSTAKA}

Anggito, Albi dan Johan Setiawan. (2018). Metodologi Penelitian Kualitatif. Cet. I; Sukabumi: CV Jejak.

Darmadi, Hamid, dkk. (2018). Pengantar Pendidikan. Cet. I; Bandung: Alfabeta,.

Khasanah, Sugianti. (2015). "Analisis Hasil Belajar Peserta Didik Pada Implementasi Scintific Approach Dalam Pembelajaran Kimia Materi Kobid di Kelas XI IPA SMA/MA”. Skripsi. Yogyakarta: UIN Sunan Kalijaga,

Setiawan, David Firma. (2018). Prosedur Evaluasi Dalam Pembelajaran. Cet. I; Yogyakarta: Deepublish.

Sugiyono. (2017). Metode Penelitian Kuantitatif, Kualitatif, Dan R\&D. Cet. I; Bandung: Alfabeta. 
Yohanes, Feri dan Sutriyon. "Analisis Pemahaman Konsep Berdasarkan Taksonomi Bloom Dalam Menyelesaikan Soal Keliling Dan Luas Segitiga Bagi Siswa Kelas VIII”. Jurnal Mitra Pendidikan, Vol. 2 no. 1 (Januari 2018).

http://ejurnalmitrapendidikan.com/index.php/ ejmp/article/view/237. (Diakses 5 Maret 2020). 